\title{
無菌製剂処理化高カロリー輸液剂でのビタミンの 長期安定性に関する薬剂学的研究
}

\author{
八野芳已, 山崎邦夫, 岩重秀二, 新田 剛, 古川佳也 \\ 国立大阪病院薬剤科*
}

\section{Pharmaceutical Studies for Long-term Stability of Vitamins in Intravenous Hyperalimentation Solutions Prepared in Clean Room}

\author{
Yoshimi Hachino, KUNIO Yamazaki, SHUJI IWASHIGE, \\ TSUYOSHI NitTA, and YoshiYa HURUKAWA \\ Department of Pharmacy, Osaka National Hospital*
}

(Received May 23, 1988)

\begin{abstract}
For the purpose of supply of intravenous hyperalimentation solutions (IVH) for home care, we examined long-term stability, especially vitamins $B_{1}, B_{2}, C$ and $A$ for two weeks to monitor changes in hospital coded prescription, IVH 1-5.

Decrease of vitamin $B_{1}$ was observed in IVH 1-4 with time. It was decreased by 27.0-40.5 $\%$ on the 14th day, while in IVH 5 the concentration decreased to at $83.7 \%$. Vitamine $\mathrm{C}$ showed the next largest decrease to $65.1 \%$ being retained two weeks in IVH 5 . In IVH 1-4, on the other hand, it remained at 83.6-94.4\%. Other two vitamins $\mathrm{B}_{2}$ and $\mathrm{A}$ remained stable at the comparatively high level of $80.9-101.4 \%$ in each preparation.

From the results, it is seemed that if the constituents of IVH are given sufficient consideration, it would be possible to guarantee the long-term stability of IVH with vitamins in the index of vitamins $B_{1}$ and $C$.
\end{abstract}

Keywords — intravenous hyperalimentation (IVH); long-term stability of vitamins; vitamin $\mathrm{B}_{1}, \mathrm{~B}_{2}, \mathrm{C}, \mathrm{A}$; home care

\section{は じめに}

高カロリー輸液剤 (IVH 製剤) は消化器疾患の外科処 置等の術前術後栄養管理に不可欠な治療手段である ${ }^{11}$. 現在はさらに IVH 製剤使用時の重篤な合併症, 主に敗 血症を防止する上から, より高度な無菌製剂が必要とさ れ, 病院薬局において無菌調製が活発に実施されてい る ${ }^{2,3)}$. また，今後拡充される在宅療法 ${ }^{4)}$ および特殊処方 への迅速な対応の実現化を目的に IVH 製剤の約束処方 による無菌調製業務の簡便化を計り, 薬学知識の有効活 用が大さな課題になると考えられる5).

この点から, 著者らはすでに IVH 製剤の調製におけ

* 大阪市東区法円坂町 2-1；2-1, Hoenzaka-machi, Higashi-ku, Osaka-shi, 540 Japan
る糖質製剂とアミノ酸製剂の基本混液について，その長 期安定性を冷所, 室温および高温 $\left(40^{\circ} \mathrm{C}\right)$ 保存における 外観変化, 溶液 $\mathrm{pH}$ 変動および微生物污染の点から検討 し，現在実施している無菌調製業務の技術面での有用性 を確認している ${ }^{6,7)}$ ，そこで今回は，IVH 製剤の在宅療法 拡充時に和ける投与設計に備え，無菌調製した IVH 製 剤中でのビタミンの冷所保存に括ける長期安定性に関し て薬剤学的に検討したので報告する.

\section{実 験 方 法}

\section{1. 試料の調製}

下記薬剤を用い，院内約束処方 (Table 1) に従い，無 菌室内のクリーンベンチ (HITACHI PCV-1303CFG3) 内で無菌調製した各製剤に高カロリー輸液用ビタミン製 剤ソービタ®（扶桑薬品，1号 : 21703C，2号 : 21604 
Table 1. Components of Hospital Coded Intravenous Hyperalimentations

\begin{tabular}{|c|c|c|c|c|c|c|}
\hline Coded name & IVH $1 \mathrm{~A}$ & IVH $1 \mathrm{~B}$ & IVH 2 & IVH 3 & IVH 4. & IVH 5 \\
\hline & A $\times 1$ & B $\times 1$ & $C \times 2$ & $D \times 2$ & A $\times 2$ & $E \times 3$ \\
\hline \multirow[t]{3}{*}{ Prescription } & $F \times 1$ & $F \times 1$ & $\mathrm{G} \times 4$ & $\mathrm{G} \times 4$ & B $\times 2$ & $G \times 3$ \\
\hline & $\mathrm{H} \quad \mathrm{x} 1$ & $\mathrm{H} \times 1$ & I $x 1$ & I $x 1$ & $F \times 4$ & I $\times 1$ \\
\hline & $\mathrm{J} \times 1$ & & & & $\mathrm{~J} \times 1$ & \\
\hline Total volume (ml) & 1100 & 1100 & 2000 & 2000 & 2400 & 2100 \\
\hline Calorie (Cal) & 585.9 & 585.9 & 1642.0 & 1925.2 & 2343.7 & 992.7 \\
\hline $\mathrm{NPC} / \mathrm{N}$ & 164.7 & 164.7 & 87.8 & 107.3 & 164.7 & 65.9 \\
\hline Total N (g) & 3.04 & 3.04 & 14.56 & 14.56 & 12.16 & 10.92 \\
\hline Amino acid $(g)$ & 21.3 & 21.3 & 90.9 & 90.9 & 85.1 & 68.4 \\
\hline $\mathrm{pH}$ & 5.69 & 5.66 & 5.65 & 5.76 & 5.61 & 5.85 \\
\hline$(\mathrm{mEq})$ & 46.8 & 46.8 & 126.0 & 189.0 & 187.2 & 142.5 \\
\hline$(\mathrm{mEq})$ & 15.0 & 15.0 & 54.0 & 54.0 & 60.0 & 30.0 \\
\hline $\mathrm{Cl}^{-} \quad(\mathrm{mEq})$ & 46.6 & 37.6 & 138.0 & 207.0 & 168.4 & 147.0 \\
\hline $\mathrm{Mg}^{++}(\mathrm{mEq})$ & 3.0 & 3.0 & 9.0 & 9.0 & 12.0 & 4.5 \\
\hline $\mathrm{Ca}^{++}(\mathrm{mEq})$ & 8.0 & -- & 9.0 & 9.0 & 16.0 & -- \\
\hline$(\mathrm{mg})$ & -- & 3.6 & 363.0 & 354.0 & 7.2 & -- \\
\hline
\end{tabular}

A:Paremental-A $A^{\circledR}$ B:Paremental- $B^{\circledR}$ C:Triparen ${ }^{\circledR}-1 \quad$ D:Triparen ${ }^{(B)}-2$ E:Physiosol ${ }^{\circledR}-3 \quad$ F:Moripron ${ }^{\circledR}$ G:Proteamin ${ }^{\circledR} 12 \mathrm{X} \quad$ H:Distiled Water I:Sohvita J:Neolamin ${ }^{\circledR}$ Multi

C, 3 号: $21530 \mathrm{C}$ ) 执よびネオラミン・マルチ®（日本 化薬，471080)を添加したものを試料とした．な扔，IVH $1(\mathrm{~A}, \mathrm{~B}), 4,5$ の調製には高カロリ一輸夜用バッグ(川 澄化学社製, $1 \mathrm{~L}, 2 \mathrm{~L}$ 用) を用い, 一方, IVH 2,3 の 調製は高カロリー輸液用製剂そのものの容器を用いた。

\section{使用薬郕}

(A) パレメンタールA（森下，SJ02A，400ml）

(B) パレメンタールB（森下, SL28A, 400ml)

（C）トリパレン 1 号 (大塚, 7H91，600ml)

(D) トリパレン 2 号 (大塚, $7 \mathrm{H} 75,600 \mathrm{ml}$ )

(E) フィジオゾール 3 号（ミドリ十字, 723GR, 500 $\mathrm{ml})$

（F）モリプロン（森下, SM02B, 200ml)

(G) プロテアミン $12 \mathrm{X}$ (田辺, $7 \mathrm{Y} 186,200 \mathrm{ml}$ )

$(\mathrm{H})$ 蒸留水 (扶桑, $21422 \mathrm{~A}, 500 \mathrm{ml}$ )

各試料 (IVH 1(A, B) 5) の組成は Table 1 亿示す と㧍りである。

\section{2. 試験条件および期間}

調製した各試料を遮光し, 冷所 $\left(4 \pm 1^{\circ} \mathrm{C}\right)$ に保存した あと，1，4，7，10，14日後に各測定項目を規定の方 法に従い実施した。

\section{3. 測定項目および方法}

外観：外観色変化を肉眼で判別した。

溶液 $\mathrm{pH}$ : 日立一堀場 $\mathrm{pH}$ メーターで経時的に測定し た.

ビタミン含量測定：試料中もっとも不安定と考兄られ るビタミン $\mathrm{B}_{1}, \mathrm{~B}_{2}, \mathrm{C}$ および $\mathrm{A} の 4$ 種を指標8) 飞, 幸 保らの方法に準じて各ビタミンの含量変化を追跡測定し た

\section{実 験 結 果}

\section{1. 外锶および溶液 $\mathbf{p H}$ 変化結果}

有色ビタミン由来による試料の黄色澄明は経時的変化 を示さなかった。一方, 試料の溶液 $\mathrm{pH}$ は初期値が5. 61 ～5.85 (Table 1) であるが，14日後では pH 5.54〜5.76 とわずかに酸性側へ移行した。

\section{2. ビタミン含量変化結果}

Fig. 1 亿示したように,ビタミン $\mathrm{B}_{1}$ がもっとも著し い変化を示した．しかし，IVH 5 では14日後です83.7\% 残存していた。一方, IVH 1 (A) 4 では 27.0〜54.9\% の残存率であった. 次に変化の認められたのはビタミン Cで, IVH 5 で最も顕著で14日後で65.1\%, IVH 1 (A) 


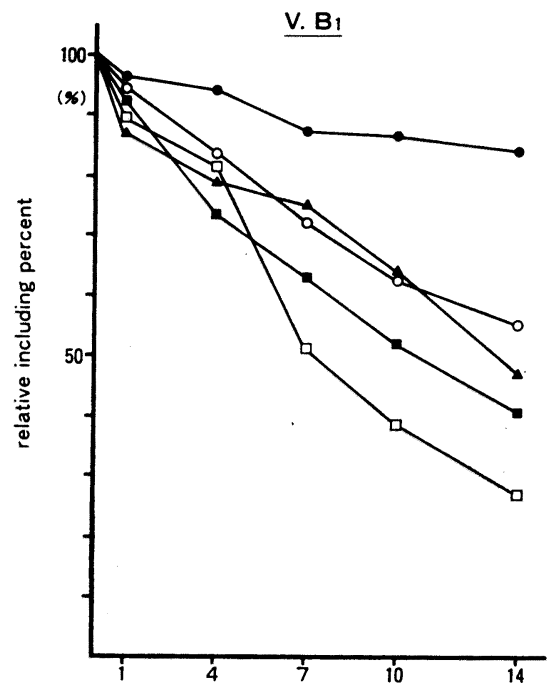

day after keeping in refrigerator (day)

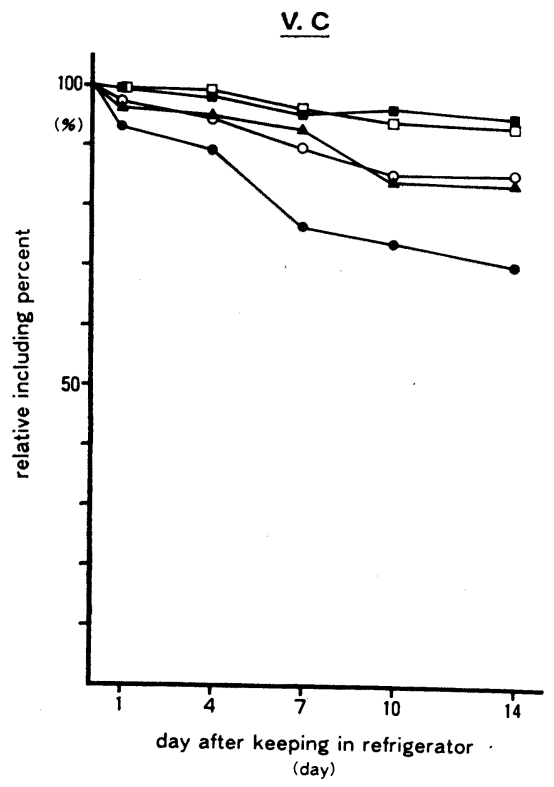

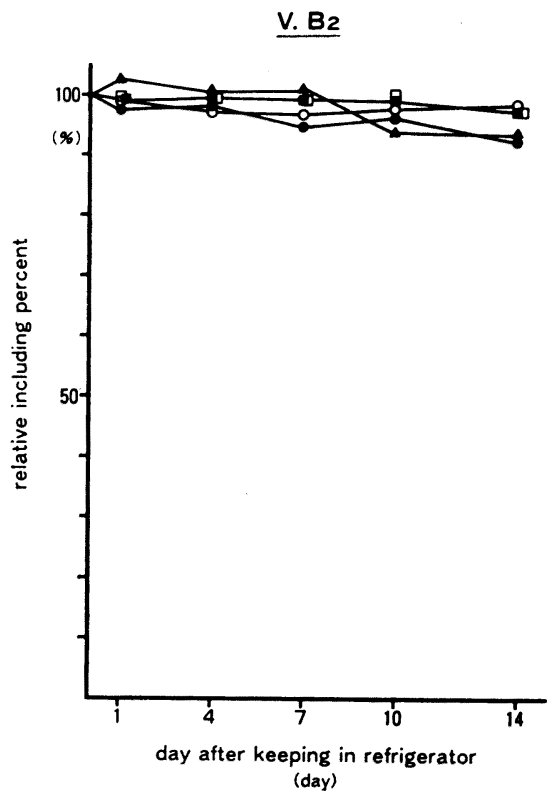

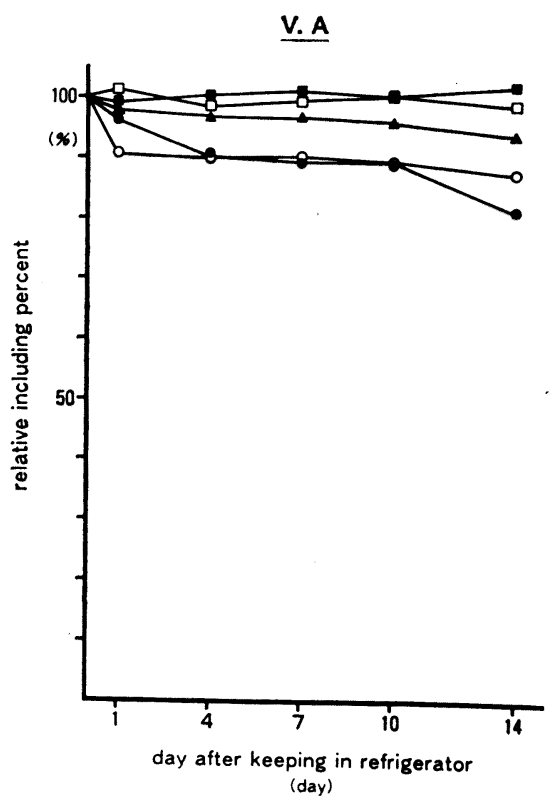

Fig. 1. Long-term Stability of Vitamins in Intravenous Hyperalimentation Solutions after Keeping in Refrigerator

V. $B_{1}$ : Thiamine hydrochloride V.B $B_{2}$ : Riboflavine phosphate V.C : Ascorbic acid V.A : Retinol parmitate closed triangles : IVH $1 \mathrm{~A}$

open squars : IVH 2

closed squars : IVH 3

open circles : IVH 4 closed circles : IVH 5 
〜4 では83.6〜94.4\%の残存率であった. これに対し， ビタミン $\mathrm{B}_{2}$ と A はほとんど経時変化は認められず，ビ タミン $\mathrm{B}_{2}$ では, 14日後の残存率が91.5〜97.4\%, ビタ ミンAのそれは, 80.9〜101.4\% と比較的安定であっ た.

\section{考察}

メイラード反応は高カロリー輸液調製時の糖質とアミ ノ酸の化学反応変化に由来することは従来より報告さ れ，外観的変化の指標として意義深いものである ${ }^{3)}$. 著 者らは以前より検討を重ね，5種の院内約束 処方製 剂 (Table 1) の保存には冷所が適していることを確認して いる7). 今回は, 冷所保存における添加ビタミン由来黄 色澄明の外観変化および溶液 $\mathrm{pH}$ の変化を 2 週間にわた り追跡観測したが，共に大さな変化は認められなかっ た。

一方, 高カロリー輸液中でのビタミン $\mathrm{B}_{1}, \mathrm{~B}_{2}, \mathrm{C}, \mathrm{A}$ の 4 種を指標に, 添加後 $1,4,7,10,14$ 日後の残存含 有量を測定した (Fig. 1). ビタミン $\mathrm{B}_{1}$ が著しい経時变 化を示したが, IVH 5 では14日後でも 83.7\% 残存して いた. また, IVH 1 から IVH 4 の 4 種では27.0〜54.9 \%の残存率であった。 ビタミン $\mathrm{B}_{1}$ の分解原因にはすで に報告のあるアミノ酸製剂に含まれる亜硫酸ナトリウム および溶液 $\mathrm{pH}$ の影響要,99少なく, むしろ糖質・電解 質製剂の組成にその要因があるものと推察される.ちな みに, ビタミンB1の経時変化が最す小さかった IVH 5 に おいては，その組成に $\mathrm{Ca}^{2+}$ と $\mathrm{HPO}_{4}-$ の 2 成分が含ま れていない点は今後さらに検討する必要があると考えて いる.これに反し，ビタミンCの経時変化はIVH 5 で顕 著で, 14日後で65.1\%, IVH 1 から IVH 4 では83.6〜
$94.4 \%$ 残存率であった. これらビタミン $\mathrm{B}_{1}$, ビタミン $\mathrm{C}$ が経時変化するのに対し，ビタミン $\mathrm{B}_{2}$ およびビタミン Aは14日後においても90\%前後の残存率を示した。

以上の結果から，ビタミン添加 IVH 製剤の使用期間 は遮光し, 冷所保存で 3 日間が妥当と考えられる5). ち なみに，3 日目における各ビタミンの残存率はFig. 1 の 結果から最も不安定なビタミン $\mathrm{B}_{1}$ で $80 \%$ 以上, ビタミン $\mathrm{B} 2, \mathrm{C}, \mathrm{A}$ では $90 \%$ 以上の残存が推計される。また，ビ タミンB 1 の溶液中での安定化を工夫すれば，ビタミン添 加 IVH 製剤の長期使用が可能となり, 在宅療法への対 応も含め, IVH 製剤の無菌製剤処理化の今後の展開に扗 がりが出るものと考えられる.

\section{文献}

1）標葉隆三郎，森 昌造：総合臨床，37，299～301 (1988).

2) 保険発 92 , 昭和 60 年 10 月 1 日

3）笠原伸元：“薬物療法と薬剤師III”, p. 81, 1986, 日本薬剤師会・日本病院薬䩹師会編

4）高木洋治, 岡田 正 : JJPEN, 7, 825 832 (1986).

5）小鴆佳代子, 前田 豊, 服部順一, 一柳千里, 南 波勝栄, 三浦康彦, 塩見武雄: JJSHP, 23, 1263 〜 1266 (1987).

6）八野芳已：昭和 62 年度薬剤科長管理研修会テキス 卜 , p. 120，1987, 厚生省保健医療局国立病院課 - 国立療養所課編

7）和田恭一, 岩重秀二, 山崎邦夫, 八野芳已, 新田 剛, 古川佳也 : JJSHP (印刷中)

8）幸保文治, 横山俊夫, 今森勝美, 入本和人: 医薬 ジャーナル，16，2014２025 (1980).

9）幸保文治，横山俊夫，佐藤英弘 : 医薬 ジャ一ナ ル, 23, 1023 1034 (1987). 